\title{
Chapter 5 \\ Urban Poverty in Developing Asia-Dichotomy Between the Income and Non-income Dimensions: Are We not Grossly Underestimating Its Incidence?
}

\section{Dibyendu Samanta}

\begin{abstract}
This paper looks at the acute non-income deprivations visible in urban developing Asia, drawing upon various evidences to drive home the point that if we just look at the income poverty in urban Asia, we are ignoring many critical dimensions of urban poverty. There are evidences to prove that there is a stark dichotomy between the income and non-income indicators of urban poverty and a gross underestimation of urban poverty in developing Asia. There is, thus, a need to broaden the definition of urban poverty in developing Asia (and, in fact, the world over), beyond just the austere threshold of meeting the survival needs of food (nutrition), to one that includes a minimal set of basic needs and capabilities for the urban population. Such an approach should take into account the huge deprivations related to shelter, access to basic infrastructure, access to health, education and social welfare, vulnerability in working conditions and working poverty. Adopting broadened and higher poverty thresholds that would faithfully report urban poverty, however, is only the initial step in the formulation of a forwardlooking urban poverty reduction strategy for developing Asia. But it is an important first step as it is critical for focusing policy attention on the right target group.
\end{abstract}

Keywords Urban poverty - Urban poverty in Asia • Income poverty • Non-income poverty $\cdot$ Underestimation of urban poverty $\cdot$ Deprivations in urban Asia

D. Samanta $(\bowtie)$

Institute of Social Sciences, New Delhi, India

e-mail: writetodibyendu@gmail.com 


\subsection{Introduction}

This is the "Asian urban century". The pace of urbanization that Asia is experiencing is quite unprecedented in the history of the urban-rural demographic transition in the world. ${ }^{1}$ While Latin America has taken 210 years (1750-1960) to advance from a $10 \%$ level of urbanization to $50 \%$, Europe has taken 150 years (18001960), North America has taken 105 years (1825-1930), and Asia is expected to take only 95 years (1930-2025) to reach the "tipping point" in the urban transition (ADB 2012a, b, c).

The per capita income in PPP US\$ of Asia $(5,578)$ was almost half of that in the world (10,740) in 2010 (UN database, accessed on 16 May 2013). There are grave disparities within Asia with respect to the current levels of per capita income between two regions: East Asia and Pacific and South Asia. While East Asia and Pacific's per capita income stood at 7,472 PPP US\$ in 2010, that of South Asia was less than half of that (3,271 PPP US\$). But per capita income in Asia has grown by $6.9 \%$ between 1990 and 2010 (the fastest anywhere in the world), as against a much moderate growth of $2.6 \%$ in the world as a whole. While per capita income in East Asia and Pacific has grown by $7.4 \%$, South Asia's per capita income has grown moderately by $4.5 \%$.

The good performance on economic growth has not necessarily translated to commensurate income poverty reduction in Asia. Even though Asia has uplifted more out of poverty than what the developing world as a whole has been able to do, and the entire poverty reduction in the developing world is seen to be largely because of Asia, poverty is still prevalent in Asia in significant numbers. Using the poverty ratios following the well-accepted $\$ 1.25$ a day poverty line at 2005 PPP that the World Bank PovcalNet database regularly updates and releases in the public domain (accessed on 16 May 2013), it can be seen that the developing world has uplifted 693.4 million out of extreme poverty during the last two decades (1990-2010), while Asia alone has uplifted 786.0 million in this period (Table 5.1).

While East Asia and Pacific has reduced its poverty incidence by $43.8 \%$ points and uplifted 675.5 million people out of poverty in the last two decades, the progress of South Asia has been moderate, with a reduction in poverty incidence by only $22.8 \%$ points and with 110.5 million people uplifted out of poverty. Out of the 1.2 billion poor in the developing world in 2010, 757.7 million are in Asia (506.8 million in South Asia and 250.9 million in East Asia and Pacific). However, Asia did not have disproportionate numbers of poor people in 2010. While Asia had $62.6 \%$ of the share of the total population in the developing world in 2010, it also had a proportionate share of $62.4 \%$ of the number of the poor. But within Asia, there are highly disproportionate shares noticeable, with East Asia and

\footnotetext{
1 "Asia" for the current background paper denotes the 45 developing economies (listed in Table 5.6) of Central and West Asia (10 countries), East Asia (5 countries), South Asia (6 countries), South-East Asia (10 countries) and the Pacific (14 countries).
} 


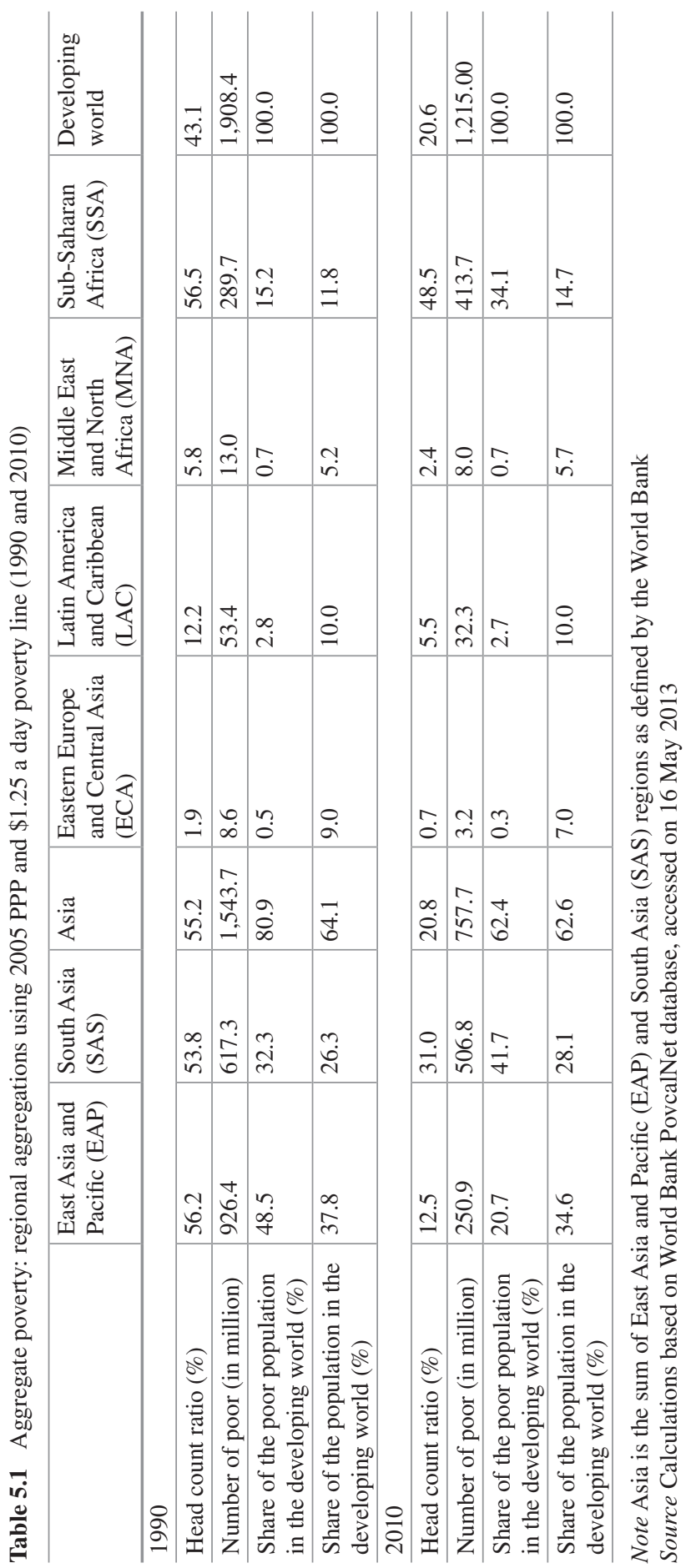


Pacific having $34.6 \%$ of the population in the developing world, but only $20.7 \%$ of the poor, and South Asia having $28.1 \%$ of population, but $41.7 \%$ of the poor in the developing world.

\subsection{Income Poverty Incidence in Urban Asia: Has There Been "Urbanization of Poverty" in Asia?}

Any study on urban income poverty is highly constrained by the lack of data. The Global Monitoring Report 2013 (World Bank and IMF 2013) gives urban poverty data for the period 1990-2008. ${ }^{2}$ Calculations reveal that, in the developing world as a whole, both in terms of the HCRs and in terms of absolute numbers, both rural poverty and urban poverty have decreased in the period 1990-2008. While the numbers of the rural poor have gone down by a huge margin of 541.2 million (37.3\% of the rural poor in 1990), urban poverty has gone down by only 25 million ( $7.9 \%$ of the urban poor in 1990) ${ }^{3}$ (Tables 5.2 and 5.3). While this phenomenon could be called "urbanization of poverty", it is much less dramatic than what has been estimated by Ravallion et al. (2007). ${ }^{4}$ The huge decline in rural poverty numbers is entirely due to East Asia and Pacific, where it declined by 562.4 million. The decline in urban poverty numbers is also due to East Asia and Pacific, where it declined by 72.5 million. As the Global Monitoring Report puts it, this has been made possible largely through the efforts of the People's Republic of China (PRC). South Asia and sub-Saharan Africa are the two regions that have shown net additions to the urban poor. In South Asia, 25.9 million have fallen into poverty in the urban areas.

In Asia as a whole, while the numbers of the rural poor went down very significantly by 574.2 million (47.4\% of the rural poor in 1990), urban poverty has also gone down, but by a much lesser margin of 46.6 million $(20.7 \%$ of the urban poor in 1990). Thus, Asia has also been witness to "urbanization of poverty" between 1990 and 2008. It must be noted that urbanization of poverty is concomitant to the urbanization of the population, and as urbanization gathers pace in Asia, there is bound to be some amount of urbanization of poverty. The question really is

\footnotetext{
2 The set of data released do not match with and is not comparable to the only other available cross-regional study by Ravallion et al. (2007) that pertains to the period 1993-2002 and used 1993 PPP and $\$ 1.08$ a day poverty line to arrive at poverty head count ratios.

3 There is a slight mismatch of the data released by the Global Monitoring Report 2013 with the World Bank PovcalNet database in that the numbers of the rural and urban poor calculated from GMR 2013 do not exactly match the number of the total poor as given in the PovcalNet, though both pertain to measuring poverty based on the line fixed at $\$ 1.25$ a day at 2005 PPP.

${ }^{4}$ Ravallion et al. (2007) had noted that over the period 1993-2002 (it is a frequently referred study), the number of people living on $\$ 1.08$ a day or less (this was the prevalent poverty line at that time) fell by 148.1 million in rural areas, but rose by 49.9 million in urban areas in the developing world. It was found that the poor have been urbanizing even more rapidly than the population as a whole, what they termed the "urbanization of poverty".
} 
Table 5.2 Aggregate poverty: regional aggregations using $\$ 1.25$ a day poverty line

\begin{tabular}{|c|c|c|c|c|c|c|c|c|c|c|}
\hline & \multicolumn{4}{|c|}{$\begin{array}{l}\text { Head count rates below } \$ 1.25 \\
\text { a day }\end{array}$} & \multicolumn{4}{|c|}{ Number of poor (in million) } & \multirow{2}{*}{\multicolumn{2}{|c|}{$\begin{array}{l}\text { Decline/ } \\
\text { increase } \\
\text { 1990-2008 } \\
\text { (in million) }\end{array}$}} \\
\hline & \multicolumn{2}{|l|}{2008} & \multicolumn{2}{|l|}{1990} & \multicolumn{2}{|l|}{2008} & \multicolumn{2}{|l|}{1990} & & \\
\hline & Rural & Urban & Rural & Urban & Rural & Urban & Rural & Urban & Rural & Urban \\
\hline $\begin{array}{l}\text { East Asia } \\
\text { and Pacific }\end{array}$ & 20.4 & 4.3 & 67.5 & 24.4 & 215.5 & 37.7 & 778.0 & 110.3 & 562.4 & 72.5 \\
\hline South Asia & 38.0 & 29.7 & 50.5 & 40.1 & 422.7 & 140.8 & 434.4 & 114.9 & 11.8 & -25.9 \\
\hline Asia & 29.4 & 13.2 & 60.2 & 30.5 & 638.2 & 178.6 & 1212.4 & 225.1 & 574.2 & 46.6 \\
\hline $\begin{array}{l}\text { Europe } \\
\text { and Central } \\
\text { Asia }\end{array}$ & 1.2 & 0.2 & 2.2 & 0.9 & 1.7 & 0.5 & 3.2 & 2.2 & 1.5 & 1.7 \\
\hline $\begin{array}{l}\text { Latin } \\
\text { America } \\
\text { and the } \\
\text { Caribbean }\end{array}$ & 13.2 & 3.1 & 21.0 & 7.4 & 16.4 & 13.8 & 27.1 & 22.8 & 10.7 & 9.0 \\
\hline $\begin{array}{l}\text { Middle } \\
\text { East and } \\
\text { North } \\
\text { Africa }\end{array}$ & 4.1 & 0.8 & 9.1 & 1.9 & 5.5 & 1.5 & 9.9 & 2.2 & 4.4 & 0.7 \\
\hline $\begin{array}{l}\text { Sub- } \\
\text { Saharan } \\
\text { Africa }\end{array}$ & 47.1 & 33.6 & 55.0 & 41.5 & 247.8 & 96.1 & 203.2 & 59.3 & -44.7 & -36.8 \\
\hline $\begin{array}{l}\text { Developing } \\
\text { world }\end{array}$ & 29.4 & 11.6 & 52.5 & 20.5 & 910.9 & 293.0 & $1,452.1$ & 318.0 & 541.2 & 25.0 \\
\hline
\end{tabular}

Note Asia is the sum of East Asia and Pacific (EAP) and South Asia (SAS) regions as defined by the World Bank

Source Calculations based on Global Monitoring Report 2013 and World Bank Indicators database for population figures

whether the shares of the urban poor have grown disproportionately to the urban shares of population.

Urban poverty incidence is not proportionate in Asia, which had $60.9 \%$ of the share of the urban poor as against $53.5 \%$ of the share of the urban population in the developing world in 2008. Moreover, what is alarming is that this incidence of urban poverty was with just an urbanization level of $38.4 \%$ in 2008 . However, the gap had decreased between 1990 and 2008. In 1990, the urban poverty incidence was even more disproportionate, with Asia having $70.8 \%$ of the share of the urban poor as against only $47.6 \%$ of the share of urban population in the developing world.

Urbanization of poverty is visible in Asia, but there are significant region-wise disparities. Of the 293 million urban poor in 2008 in the developing world, in what is extremely disproportionate, $48.1 \%$ was in South Asia (which had only $18.8 \%$ of the share of the urban population in the developing world); another $12.9 \%$ was in East Asia and Pacific (which had $34.8 \%$ of the share of the urban population in the developing world). While in East Asia and Pacific, the incidence of rural poverty went down by a large margin of $47.1 \%$ points, the incidence of urban poverty 
Table 5.3 Aggregate poverty: regional aggregations using $\$ 1.25$ a day poverty line (shares of the numbers of poor and population)

\begin{tabular}{|c|c|c|c|c|c|c|c|c|}
\hline & \multicolumn{4}{|c|}{$\begin{array}{l}\text { Share of the poor population in } \\
\text { the developing world }(\%)\end{array}$} & \multicolumn{4}{|c|}{$\begin{array}{l}\text { Share of the population in the } \\
\text { developing world }(\%)\end{array}$} \\
\hline & \multicolumn{2}{|l|}{2008} & \multicolumn{2}{|l|}{1990} & \multicolumn{2}{|l|}{2008} & \multicolumn{2}{|l|}{1990} \\
\hline & Rural & Urban & Rural & Urban & Rural & Urban & Rural & Urban \\
\hline East Asia and Pacific & 23.7 & 12.9 & 53.6 & 34.7 & 34.1 & 34.8 & 41.7 & 29.1 \\
\hline South Asia & 46.4 & 48.1 & 29.9 & 36.1 & 35.9 & 18.8 & 31.1 & 18.5 \\
\hline Asia & 70.1 & 60.9 & 83.5 & 70.8 & 70.0 & 53.5 & 72.8 & 47.6 \\
\hline Europe and Central Asia & 0.2 & 0.2 & 0.2 & 0.7 & 4.7 & 10.1 & 5.3 & 15.8 \\
\hline $\begin{array}{l}\text { Latin America and the } \\
\text { Caribbean }\end{array}$ & 1.8 & 4.7 & 1.9 & 7.2 & 4.0 & 17.6 & 4.7 & 19.8 \\
\hline $\begin{array}{l}\text { Middle East and North } \\
\text { Africa }\end{array}$ & 0.6 & 0.5 & 0.7 & 0.7 & 4.3 & 7.4 & 3.9 & 7.5 \\
\hline Sub-Saharan Africa & 27.2 & 32.8 & 14.0 & 18.7 & 17.0 & 11.3 & 13.4 & 9.2 \\
\hline Developing world & 100.0 & 100.0 & 100.0 & 100.0 & 100.0 & 100.0 & 100.0 & 100.0 \\
\hline
\end{tabular}

Note Asia is the sum of East Asia and Pacific (EAP) and South Asia (SAS) regions as defined by the World Bank

Source Calculations based on Global Monitoring Report 2013 and World Bank Indicators database for population figures

also went down by a smaller margin of $20.1 \%$ points. In South Asia, on the other hand, while rural poverty went down by $12.5 \%$ points, the incidence of urban poverty fell by $10.4 \%$ points (though in absolute numbers, it went up by 25.9 million). Thus, while in East Asia and Pacific, the pace of decline in rural poverty outstripped the urban poverty decline, in South Asia, there was an increase in the numbers of the urban poor as against a decrease in the numbers of the rural poor.

\subsection{Why Is Examining Only Income Poverty in Urban Asia not Enough?}

If urban poverty measurement in Asia takes into account just the numbers of people living below an income poverty line (fixed in terms of income at $\$ 1.25$ a day at 2005 PPP to make cross-national, regional and global comparisons possible), the urban poverty incidence, though significant in terms of numbers, does not appear to be very grave, with only $13.2 \%$ of the urban population living below the poverty line (29.7 \% being the HCR in South Asia and only $4.3 \%$ in East Asia and Pacific) in 2008.

But, as ADB (2013a, b, c), Haddad (2013) and Satterthwaite (2004) have argued, the characteristics of urban poverty are totally different from that of rural poverty. First, unlike rural poverty, urban poverty is inherently multidimensional in nature, and its many dimensions relate to the unmet needs and inherent vulnerability of the poor as manifested by their lack of access to economic and livelihood 
resources, land and housing, physical infrastructure and services, health and education facilities, social security network and empowerment. Second, urban poverty is a highly monetary phenomenon because unlike the rural poor, the urban poor have to buy almost everything from the market, making them more vulnerable to internal and external shocks to the economy. Third, urban areas have the extremes of wealth and poverty often existing side by side, and urban averages hide deprivation on a scale rarely seen in rural areas. Thus, urban inequality reduction ought to be a critical strategy for urban poverty reduction, without which much of the potential poverty reduction would not be possible on the ground. Fourth, informal ties and reciprocities are likely to be more fragile in the more mobile context of urban areas. Poverty targeting becomes more complicated due to a greater mobility of residence. Fifth, institutional complexity is likely to be higher in urban areas, with more competition between various types of formal and informal sources of authority. Sixth, access to services may appear enhanced in urban areas, but often their quality is uneven and the competition for them is intense. Satterthwaite (2004) and Mitlin (2004) had concluded that urban poverty is often grossly underestimated. Official statistics tend to systematically under-report urban poverty due to lack of cost-of-living adjustments like transport and housing in the income/consumption poverty estimates, lack of disaggregation within urban areas and inadequate definitions of access to water supply and sanitation, adequate shelter or other infrastructure variables.

This paper looks at the acute non-income deprivations visible in urban Asia, drawing upon evidences from different databases such as ADB, UN-HABITAT, WHO, UNICEF, UNESCO, UN, ILO and the World Bank to drive home the point that if just the income poverty in urban Asia is considered, many critical dimensions of urban poverty are overlooked, resulting in a gross underestimation of its incidence.

\subsection{Dimensions of Non-income Poverty in Urban Asia: How Acute Are the Deprivations?}

\subsubsection{Shelter Poverty}

Informal settlements in Asian cities provide much of the total supply of land and housing to the poor in Asian cities, as formal planned housing is often not available at prices, locations and flexible conditions that make them accessible to the poor. Informal settlements, however, provide a poorer quality of service and carry uncertainty about title and tenure. Between 30 and $60 \%$ of urban dwellers in developing Asia live without secure tenure (Bartlett 2011).

In order to measure the progress on the Millennium Development Goal (MDG) related to slums, UN-HABITAT has adopted a functional definition of slums based on the household as the basic unit of analysis and five measurable shelter deprivation indicators: "A slum household consists of one or a group of individuals living 
under the same roof in an urban area, lacking one or more of the following five amenities: (1) durable housing (a permanent structure providing protection from extreme climatic conditions); (2) sufficient living area (no more than three people sharing a room); (3) access to improved water (water that is sufficient, affordable and can be obtained without extreme effort); (4) access to improved sanitation facilities (a private toilet, or a public one shared with a reasonable number of people); and (5) secure tenure (de facto or de jure secure tenure status and protection against forced eviction). Since information on secure tenure is not available for most countries, only the first four indicators are used to define slum households, and then to estimate the proportion of the urban population living in slums" (UN-HABITAT 2010). These criteria are very different from and more broadbased than those used by various countries in the region. This is the reason that the UN-HABITAT slum data are at a significant variance from, and often much higher than, national estimates.

UN-HABITAT statistics show that in UN-HABITAT (2012), 523.2 million slum dwellers, or $60.7 \%$ of the developing world's slum population, live in Asia (Table 5.4), out of which 206.5 million are in East Asia and 200.0 million in South Asia. Thus, $77.8 \%$ of the slum population in Asia is concentrated in these two UN regions. 5

Table 5.5 has a very interesting story to tell. What is noticeable from Table 5.5 is that between 1990 and 2009, slum population in terms of the proportions of urban population seems to have gone down in all the Asian countries for which data are available. However, slum population figures for 2009 in absolute numbers have a different story to tell. The PRC has seen an addition of 48.9 million to its slum population in the last two decades, and Pakistan has added another 11.9 million. Nepal, the Philippines and Viet Nam have also shown net additions to their slum populations in the last two decades. In Bangladesh, Nepal, Pakistan and the Philippines, more than $40 \%$ of the urban populations are seen to be living in slums. India has seen slum population decline by 16.3 million in the same period, the highest decline seen in Asia.

Slum population in the PRC in 2009 was 180.6 million (29.1\%) and in India 104.7 million $(29.4 \%)$. To put these numbers into perspective, using the $\$ 1.25$ a day at 2005 PPP, the urban poverty incidence in the PRC in terms of income levels in 2009 was only $0.6 \%$ of the urban population, while in India, in 2009-2010, using the same poverty line, the income poverty incidence in urban India was $28.9 \%$ (though according to the national urban poverty line, the incidence was much lower at $20.9 \%$ ). Thus, while the urban poverty numbers and the numbers of people living in slums match quite closely in case of India, there is a huge disparity, of unbelievable proportions, in the PRC.

How do we explain the PRC's case? Foggin (2008) has noted that because of the rapid influx of rural labour into the cities, scattered villages within cities have grown up, which are often hidden behind walls. These are the "new slums" in the PRC.

\footnotetext{
5 The UN subregions of Asia are significantly different from the World Bank subregions of Asia.
} 
Table 5.4 Slum population (absolute numbers and proportions), Asia: 1990, 2000, 2010, 2012

\begin{tabular}{l|l|l|l|l|l|l|l|l}
\hline \multirow{2}{*}{ Major region or area } & \multicolumn{4}{|c|}{$\begin{array}{l}\text { Urban slum population at mid-year } \\
\text { by region (million) }\end{array}$} & \multicolumn{3}{l}{$\begin{array}{l}\text { Proportion of urban population } \\
\text { living in slum (\%) }\end{array}$} \\
\cline { 2 - 11 } & 1990 & 2000 & 2010 & 2012 & 1990 & 2000 & 2010 & 2012 \\
\hline Eastern Asia & 154.2 & 191.6 & 197.5 & 206.5 & 43.7 & 37.4 & 28.2 & 28.2 \\
\hline Southern Asia & 181.7 & 194.4 & 190.6 & 200.5 & 57.2 & 45.8 & 35.0 & 35.0 \\
\hline South-eastern Asia & 68.9 & 78.2 & 76.5 & 79.9 & 49.5 & 39.6 & 31.0 & 31.0 \\
\hline Western Asia & 17.8 & 22.0 & 34.1 & 35.7 & 22.5 & 20.6 & 24.6 & 24.6 \\
\hline Oceania & 0.4 & 0.5 & 0.6 & 0.6 & 24.1 & 24.1 & 24.1 & 24.1 \\
\hline Asia-Pacific region & 422.9 & 486.6 & 499.4 & 523.2 & 39.4 & 33.5 & 28.6 & 28.6 \\
\hline Developing world & 650.4 & 759.9 & 820.0 & 862.6 & 46.2 & 39.4 & 32.6 & 32.7 \\
\hline
\end{tabular}

Source United Nations Human Settlements Programme (UN-HABITAT), Global Urban Indicators Database 2012

Table 5.5 Slum population (absolute numbers and proportions), some Asian economies: 1990, 1995, 2000, 2005, 2007 and 2009

\begin{tabular}{|c|c|c|c|c|c|c|c|c|c|c|c|c|}
\hline \multirow[t]{2}{*}{ Economy } & \multicolumn{6}{|c|}{$\begin{array}{l}\text { Proportion of urban population living } \\
\text { in slums }(\%)\end{array}$} & \multicolumn{6}{|c|}{ Slum population at mid-year (million) } \\
\hline & 1990 & 1995 & 2000 & 2005 & 2007 & 2009 & 1990 & 1995 & 2000 & 2005 & 2007 & 2009 \\
\hline Bangladesh & 87.3 & 84.7 & 77.8 & 70.8 & 66.2 & 61.6 & 20.0 & 23.5 & 25.8 & 27.8 & 27.8 & 27.5 \\
\hline Cambodia & - & - & - & 78.9 & - & - & - & - & - & 2.1 & - & - \\
\hline The PRC & 43.6 & 40.5 & 37.3 & 32.9 & 31.0 & 29.1 & 131.7 & 151.4 & 169.1 & 183.5 & 182.9 & 180.6 \\
\hline India & 54.9 & 48.2 & 41.5 & 34.8 & 32.1 & 29.4 & 121.0 & 122.2 & 119.7 & 112.9 & 109.1 & 104.7 \\
\hline Indonesia & 50.8 & 42.6 & 34.4 & 26.3 & 23.0 & 23.0 & 27.6 & 29.0 & 29.7 & 24.8 & 22.5 & 23.3 \\
\hline Lao PDR & - & - & - & 79.3 & - & - & - & - & - & 1.3 & - & - \\
\hline Mongolia & 68.5 & 66.7 & 64.9 & 57.9 & 57.9 & - & 0.9 & 0.9 & 0.9 & 0.9 & 0.9 & - \\
\hline Myanmar & - & - & - & 45.6 & - & - & - & - & - & 6.7 & - & - \\
\hline Nepal & 70.6 & 67.3 & 64.0 & 60.7 & 59.4 & 58.1 & 1.2 & 1.6 & 2.1 & 2.6 & 2.9 & 3.1 \\
\hline Pakistan & 51.0 & 49.8 & 48.7 & 47.5 & 47.0 & 46.6 & 18.1 & 20.7 & 23.9 & 27.2 & 28.5 & 30.0 \\
\hline $\begin{array}{l}\text { The } \\
\text { Philippines }\end{array}$ & 54.3 & 50.8 & 47.2 & 43.7 & 42.3 & 40.9 & 16.5 & 17.2 & 17.6 & 18.0 & 18.1 & 18.3 \\
\hline Thailand & - & - & - & 26.0 & 26.5 & 27.0 & - & - & - & 5.5 & 5.8 & 6.1 \\
\hline Viet Nam & 60.5 & 54.6 & 48.8 & 41.3 & 38.3 & 35.2 & 8.1 & 8.9 & 9.4 & 9.5 & 9.4 & 9.2 \\
\hline
\end{tabular}

Source UN-HABITAT, Global Urban Indicators Database 2012

Miller (2013) has noted that 250 million migrant workers have moved to cities in the PRC for the sake of a better life between 1980 and 2011. Since the discriminatory Chinese household registration system (hukou), implemented in the PRC in 1958, remains in effect (except in small and medium towns) even today, most of the migrants are forced to live in squalor and highly congested houses that lack even the basic amenities. The hukou system in the PRC uses residency permits to divide Chinese citizens into urban and rural dwellers. A person's hukou status determines his or her access to state services. Under normal circumstances, a person with a rural hukou status is not eligible for state services in urban areas and vice versa. Hukou status is primarily inherited from one's parents at the time of birth-so 
children born in urban areas to parents with rural hukou end up being designated as rural hukou holders. This situation has led academics and human rights activists to describe the hukou system as being discriminatory in nature (Cheng 2003; Solinger 2004). In February 2012, restrictions on migration were relaxed in the small and medium towns in the PRC. But hukou still remains in force in the large cities of the PRC (provincial cities such as Beijing, Shanghai, Tianjin and Chongqing; special cities such as Shenzhen and Dalian), which are the destinations of most rural-urban migration (World Bank and IMF 2013).

On the one hand, if not for the PRC, there would have been no decline in the numbers of the poor (or urban poor) in purely income terms in the developing world over the last two decades. On the other hand, the slum population numbers (definition involving durable housing, sufficient living area, access to improved water and access to improved sanitation facilities) reveal that examining income poverty is not enough - a thorough investigation of the non-income indicators is essential for a more accurate measurement of urban poverty. Indonesia had a slum

Table 5.6 Urban poverty numbers and slum population (shelter and service deprivation) numbers, some Asian economies: latest year

\begin{tabular}{|c|c|c|c|c|c|c|}
\hline & \multicolumn{2}{|c|}{$\begin{array}{l}\text { Urban poverty inci- } \\
\text { dence (World Bank } \\
\text { PovcalNet } \$ 1.25 \mathrm{a} \\
\text { day) }\end{array}$} & \multicolumn{2}{|c|}{$\begin{array}{l}\text { Urban poverty incidence } \\
\text { (national) }\end{array}$} & \multicolumn{2}{|c|}{$\begin{array}{l}\text { Proportion of } \\
\text { urban popula- } \\
\text { tion living in } \\
\text { slums }\end{array}$} \\
\hline & Year & $\begin{array}{l}\mathrm{HCR} \\
(\%)\end{array}$ & $\begin{array}{l}\text { Year of national } \\
\text { survey }\end{array}$ & $\begin{array}{l}\mathrm{HCR} \\
(\%)\end{array}$ & Year & $\%$ \\
\hline \multicolumn{7}{|c|}{ Central and West Asia } \\
\hline Pakistan & & & 2006 & 13.1 & 2009 & 46.6 \\
\hline \multicolumn{7}{|l|}{ East Asia } \\
\hline The PRC & 2009 & 0.6 & 2009 & - & 2009 & 29.1 \\
\hline Mongolia & & & 2009 & 30.6 & 2007 & 57.9 \\
\hline \multicolumn{7}{|l|}{ South Asia } \\
\hline Bangladesh & & & 2010 & 21.3 & 2009 & 61.6 \\
\hline India & $\begin{array}{l}2009- \\
2010\end{array}$ & 28.9 & 2010 & 20.9 & 2009 & 29.4 \\
\hline Nepal & & & 2011 & 15.5 & 2009 & 58.1 \\
\hline \multicolumn{7}{|c|}{ Southeast Asia } \\
\hline Cambodia & & & 2007 & 11.8 & 2005 & 78.9 \\
\hline Indonesia & 2010 & 18.3 & 2011 & 9.2 & 2009 & 23.0 \\
\hline Lao PDR & & & 2008 & 17.4 & 2005 & 79.3 \\
\hline Myanmar & & & 2010 & 15.7 & 2005 & 45.6 \\
\hline Thailand & & & 2010 & 3.0 & 2009 & 27.0 \\
\hline Viet Nam & & & 2008 & 3.3 & 2009 & 35.2 \\
\hline
\end{tabular}

Source World Bank PovcalNet database, accessed on 16 May 2013; Framework of Inclusive Growth Indicators 2012, ADB; UN Millennium Database 2012; World Development Indicators database 2012; UN-HABITAT, Global Urban Indicators Database 2012 
population (according to the UN-HABITAT definition) of 23.3 million in 2009, as against a $\$ 1.25$ a day number of urban poor of 23.5 million in 2010 . Thus, in Indonesia's case, the numbers largely match (Table 5.6). Table 5.6 juxtaposes the income poverty against the slum population numbers (which is really shelter and service deprivation combined).

There are huge disparities between the urban poverty HCRs and the share of slum population (in the urban population), which clearly bring forth the dichotomy between the income and the non-income indicators of urban poverty. The least gap among the two is for India, while the highest gap is seen in the case of Lao PDR and Cambodia (the difference being more than $60 \%$ between the two). Very high gaps of more than $40 \%$ are also noticed in the cases of Bangladesh and Nepal.

Shelter deprivations are not just restricted to the slums proper, but are also alarmingly high across the non-slum households in many Asian countries (UN-HABITAT, Global Urban Indicators Database 2010). According to the UN-HABITAT classification, the areas of non-slums- $16.4 \%$ in Bangladesh, $18.5 \%$ in Pakistan, $9.2 \%$ in Nepal and $13.8 \%$ in Uzbekistan-are such that $75 \%$ or more of the total number of households in them can be classified as "slum"6 households.

\subsection{Congested Living}

Unlike their counterparts in other regions, the residents in Asian cities live in very congested areas. Average urban densities in Asia range from 10,000 to 20,000 per $\mathrm{km}^{2}$, which is almost double of that in Latin America, triple of that in Europe and 10 times of that in US cities (UN-HABITAT 2010).

Although many Asians do not live in cities, those who do are crowded into relatively small areas. Of the top 10 densest megacities (over 10 million population) in the world, seven are in Asia. Dhaka is the densest city in the world, followed by Mumbai (Fig. 5.1). Land markets in high-density cities reflect the growing demand for land in central urban areas. Scarce supply drives up land prices in prime locations, forcing the urban poor into slums and the peripheries. The urban poor live in informal settlements or in conditions that are more congested than where the non-poor live.

\footnotetext{
6 This definition is not the national definition of slum, but the more stringent definition as adopted by the UN-HABITAT.
} 


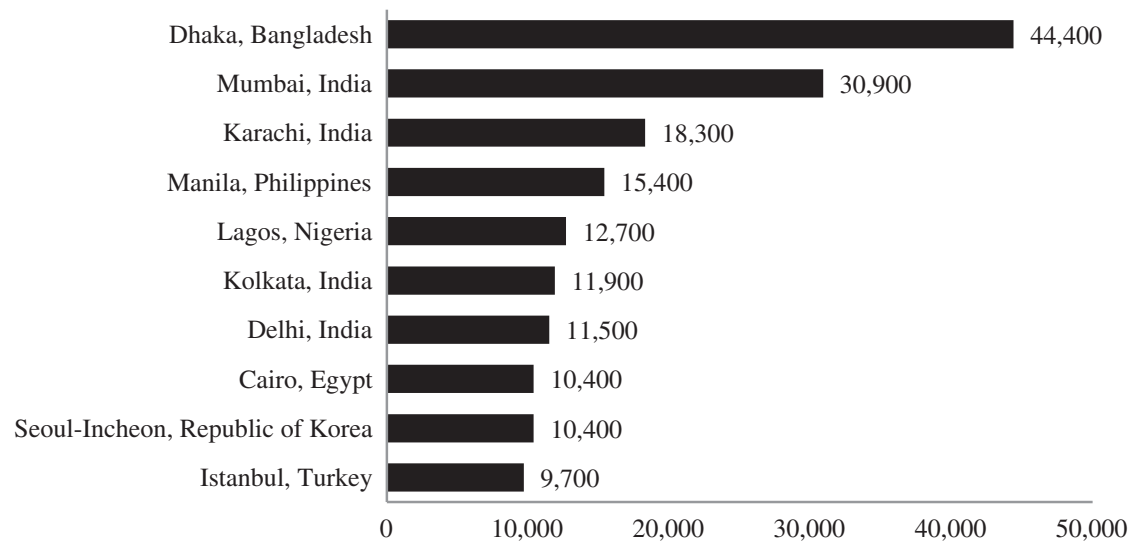

Fig. 5.1 Top ten densest cities (over 10 million population) in the world, population density (persons per km2): 2012 Source http://www.demographia.com

\subsection{Urban Service Deficits and Deprivations}

The high degree of "urban service deprivation" suggests that the official urban poverty figures do not fully reflect the poor state of affairs in urban Asia (Table 5.7). Only $66 \%$, on an average, of the population in urban Asia has access to piped water supply on premises. The situation with respect to drinking water supply in urban areas is especially bad in Afghanistan, Bangladesh, Azerbaijan, Cambodia and Lao PDR.

The sanitation facilities in urban areas are even worse- $15 \%$ of the population in urban Asia, on an average, has seen no improvement with respect to the sanitation facilities. The situation is abysmal in Afghanistan, Bangladesh, India and Nepal. Thirteen per cent of households in urban Asia still are forced to use shared latrines. Thirty-six per cent of the urban population in Nepal, $31 \%$ in Mongolia, $26 \%$ in Bangladesh and $24 \%$ in the PRC are forced to use community latrines. Even in 2010, 72.7 million people in the urban Asia were openly defecating. The situation with regard to open defecation in urban areas is specifically worse in countries such as India and Indonesia, where 51.5 and 14.9 million people, respectively, still openly defecate.

Settlements of the urban poor often lack access to water and sanitation infrastructure. These communities exist off the grid and rely on private, small-scale distributors of water, such as vendors or public taps. The result is that most urban slum dwellers pay several times more than their higher-income counterparts (UNHRC 2012). 


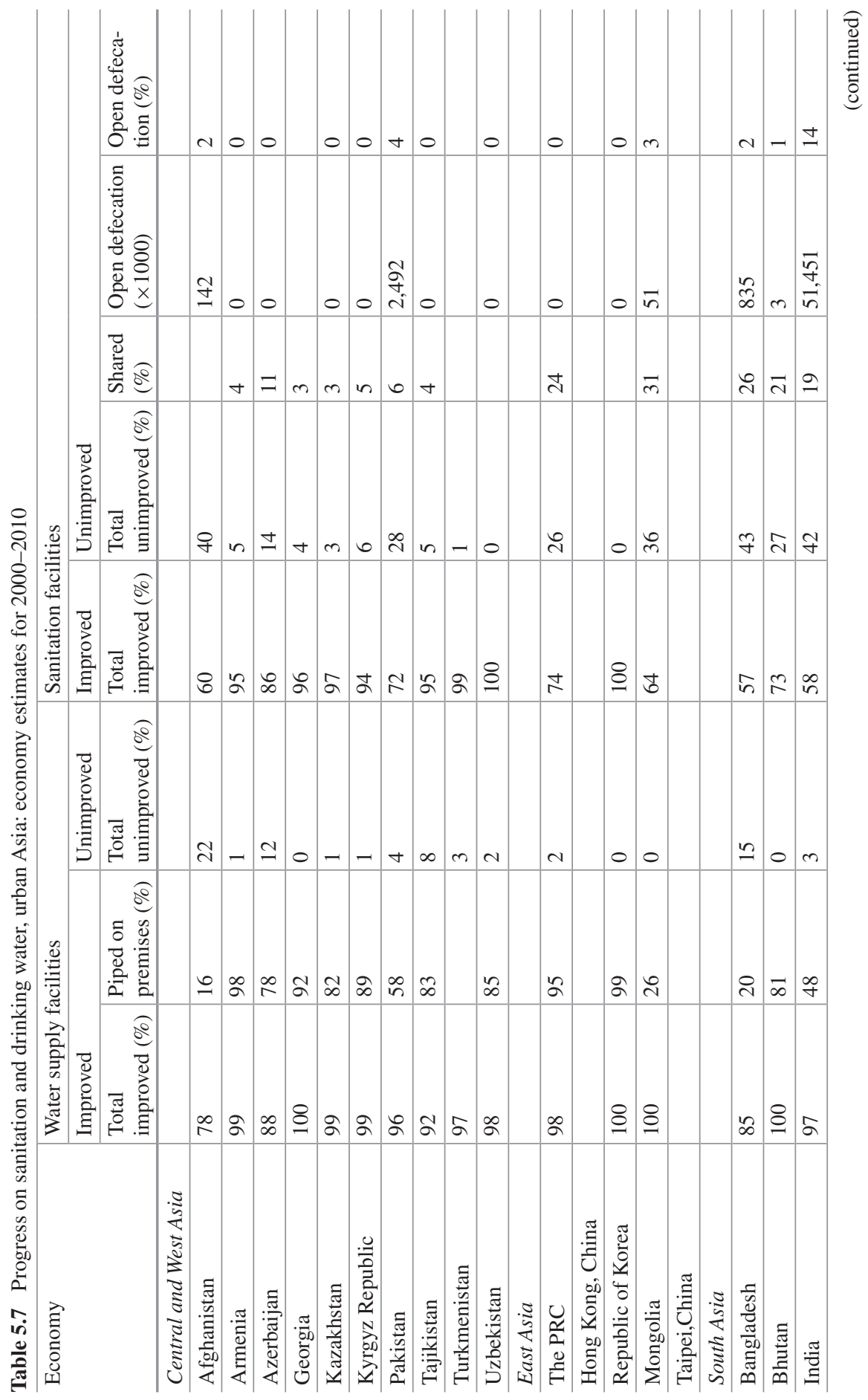




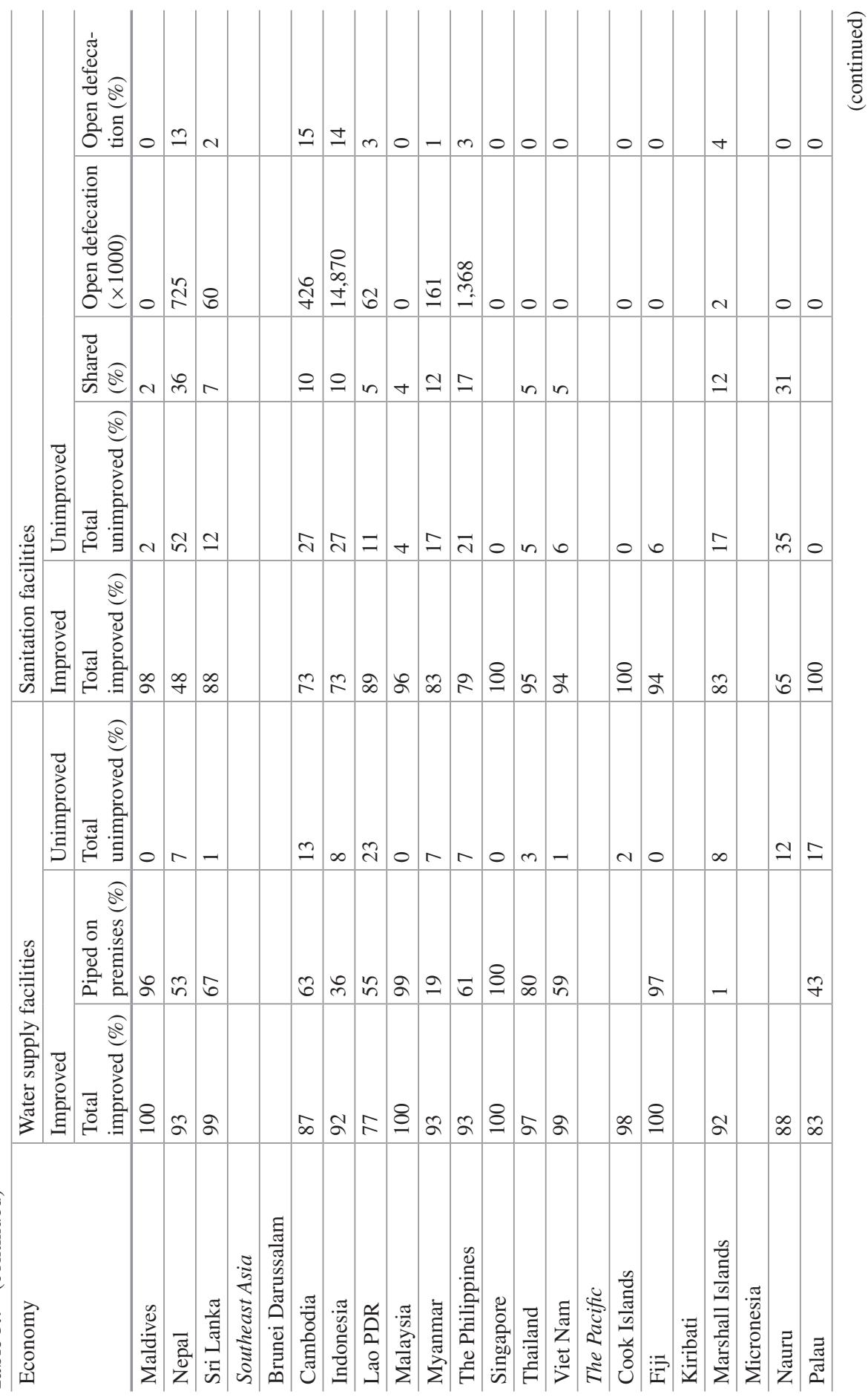




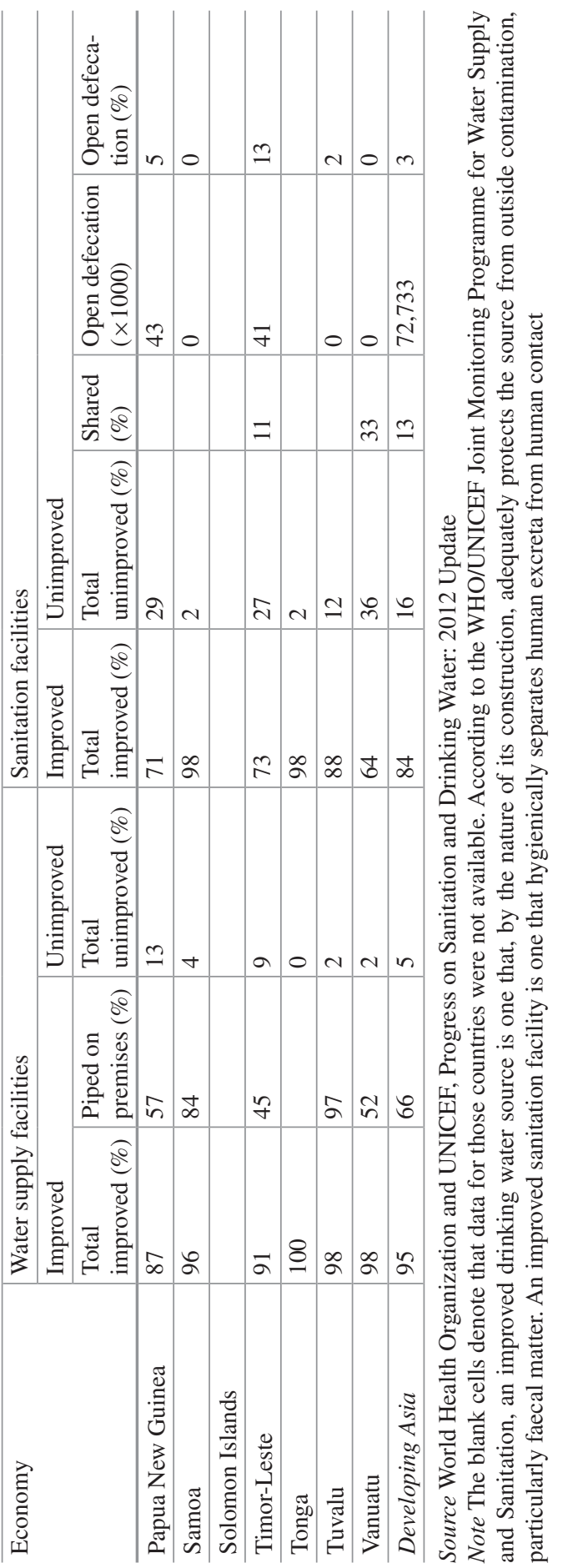




\subsection{Social Poverty: Lack of Access to Education, Health and Social Security Systems}

There is a general lack of access to health, education and social security systems in developing Asia, especially South Asia. Social deprivations are bound to be even greater among the urban poor, though there is no data set available to support this.

In 2012, developing Asia had an average school life expectancy ${ }^{7}$ of only 11.4 years as against an average of 16.5 in North America and Western Europe (the developed countries) (Table 5.8). The school life expectancy in developing Asia varied from a high of 17.2 in the Republic of Korea to as low as 7.3 in Pakistan.

The child mortality rates in urban Asia in 2010 ranged from 3 per 1,000 live births in Samoa to 78 in Pakistan. ${ }^{8}$ Between 1990 and 2010, all economies in developing Asia succeeded in reducing under-five mortality rates, but very high urban child mortality rates were observed in Bangladesh. Urban Asia, on an average, has an under-five mortality rate of 41 as against 7 in North America and Western Europe (ADB 2012a).

Immunization coverage among 1 -year-olds, ${ }^{9}$ on an average, in urban Asia was $79 \%$ as against $96 \%$ in urban North America and Western Europe in 2010. It varied from a high of $98 \%$ in Maldives and Kazakhstan, to a low of $38 \%$ in Azerbaijan. Urban India also had abysmally low immunization coverage at $56 \%$.

WHO (2013) has estimated that 100 million people in the world are pushed under the poverty line each year because they use health services for which they are forced to pay out of their own pockets, due to the lack of public health services. ${ }^{10}$ In 2011, Turkmenistan had the highest (100\%) out-of-pocket health expenditure as a proportion of total health expenditure both in Asia and in the world. Bangladesh and India had an exceptionally high out-of-pocket health expenditure proportion of 96.6 and $86.0 \%$, respectively. Nepal had a proportion of $90.4 \%$, Pakistan $86.3 \%$ and the PRC $78.8 \%$ in 2011. In comparison, the average out-of-pocket health expenditure in the developed economies was $49.6 \%$ in 2011.

\footnotetext{
${ }^{7}$ School life expectancy is the number of years that children can expect to spend in school given current enrolment ratios.

${ }^{8}$ Under-five mortality rate measures the probability (expressed as a rate per 1,000 live births) of a child born in a specified year dying before reaching the age of five if subject to current agespecific mortality rates.

${ }^{9}$ Child immunization measures the percentage of children aged 12-23 months who received vaccinations before 12 months or at any time before the survey.

${ }^{10}$ Household out-of-pocket expenditure on health comprises cost-sharing, self-medication and other expenditure paid directly by private households.
} 

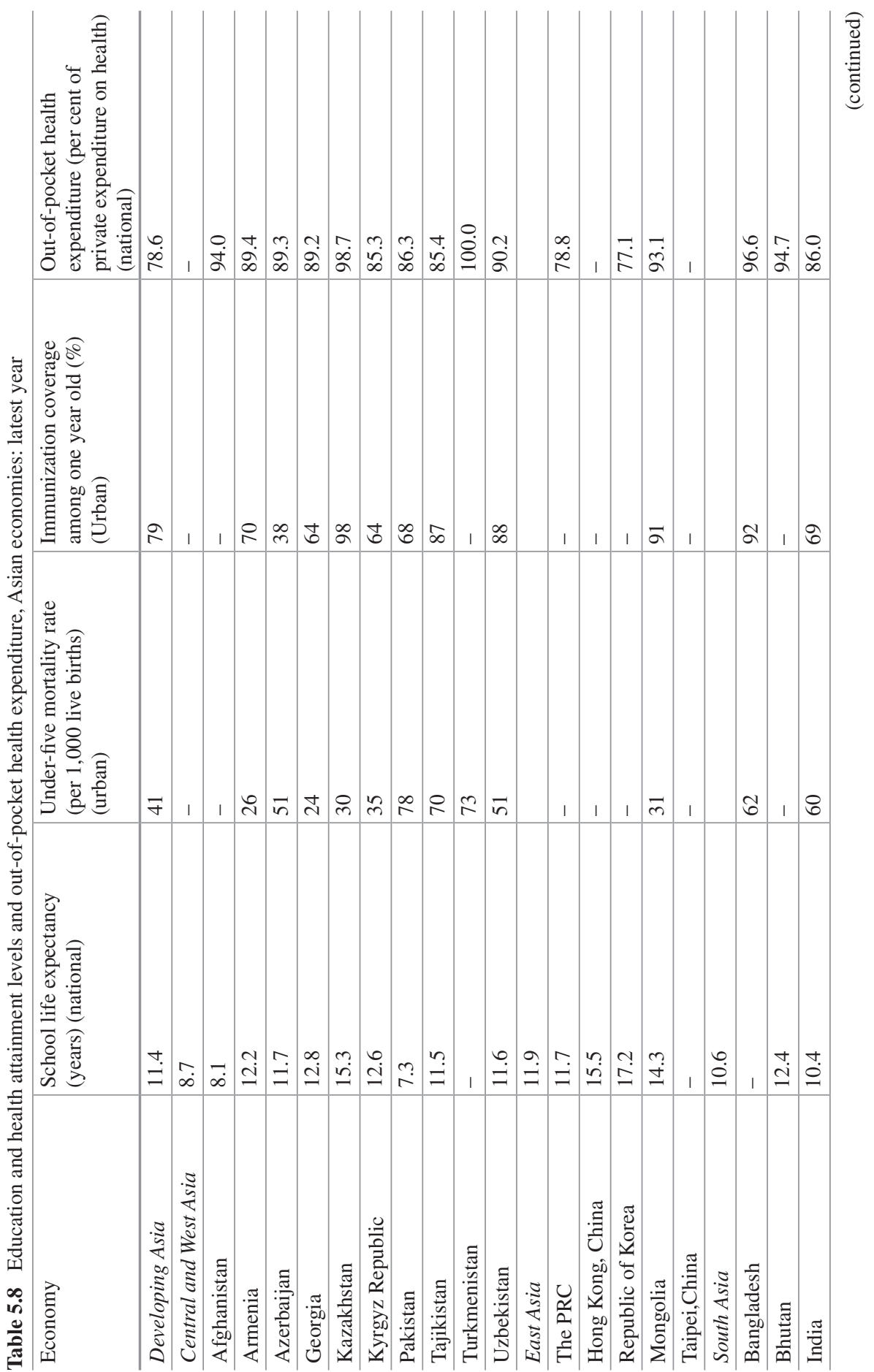

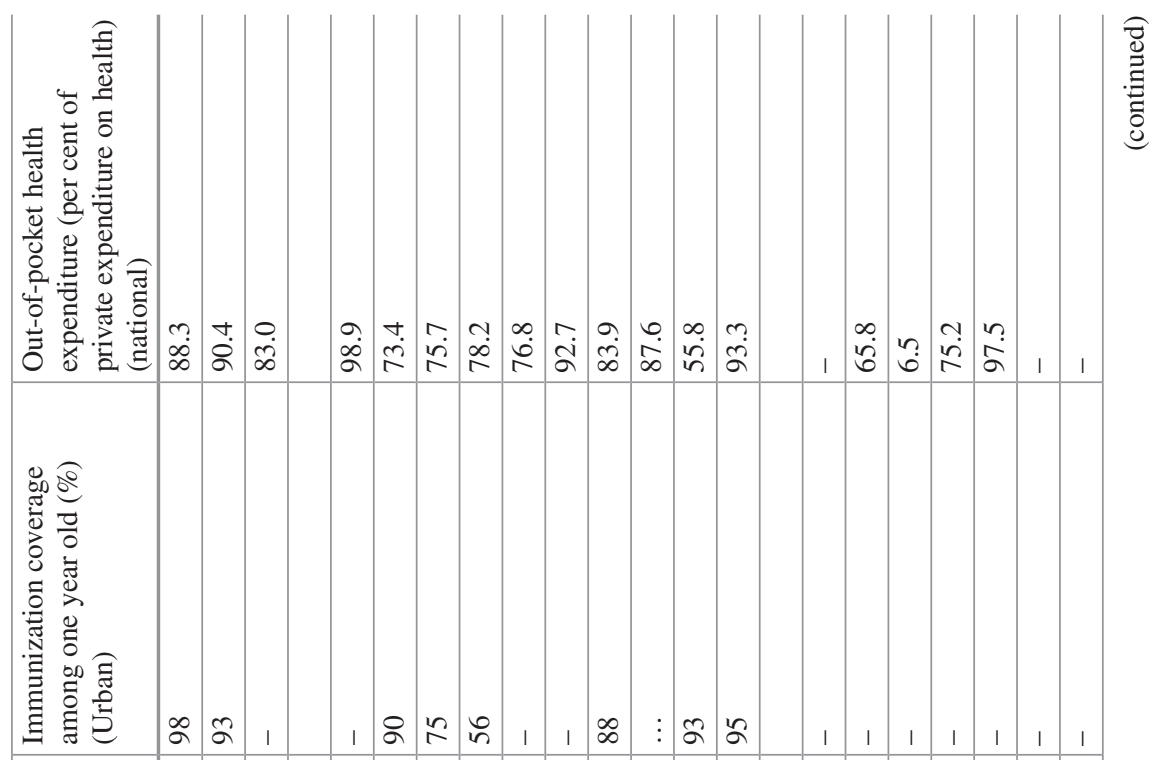

䒕

昰昰

范

2

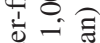

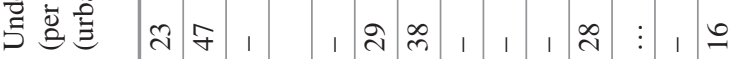

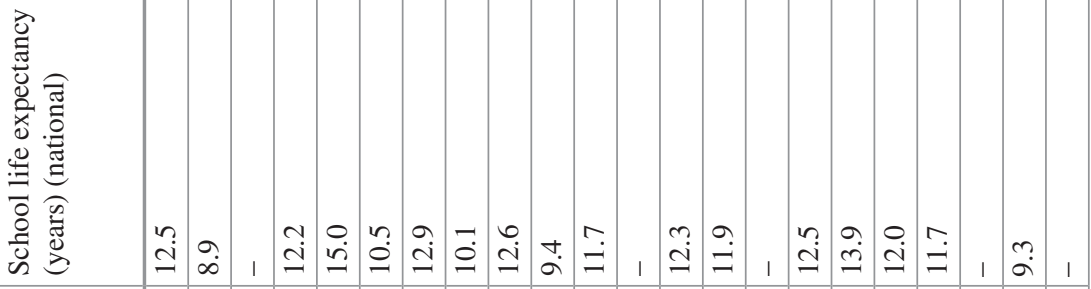

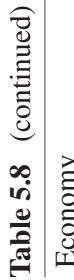

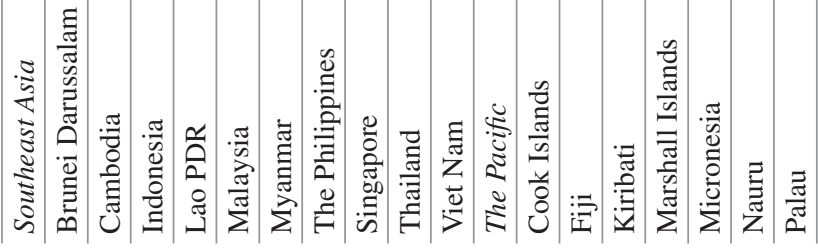




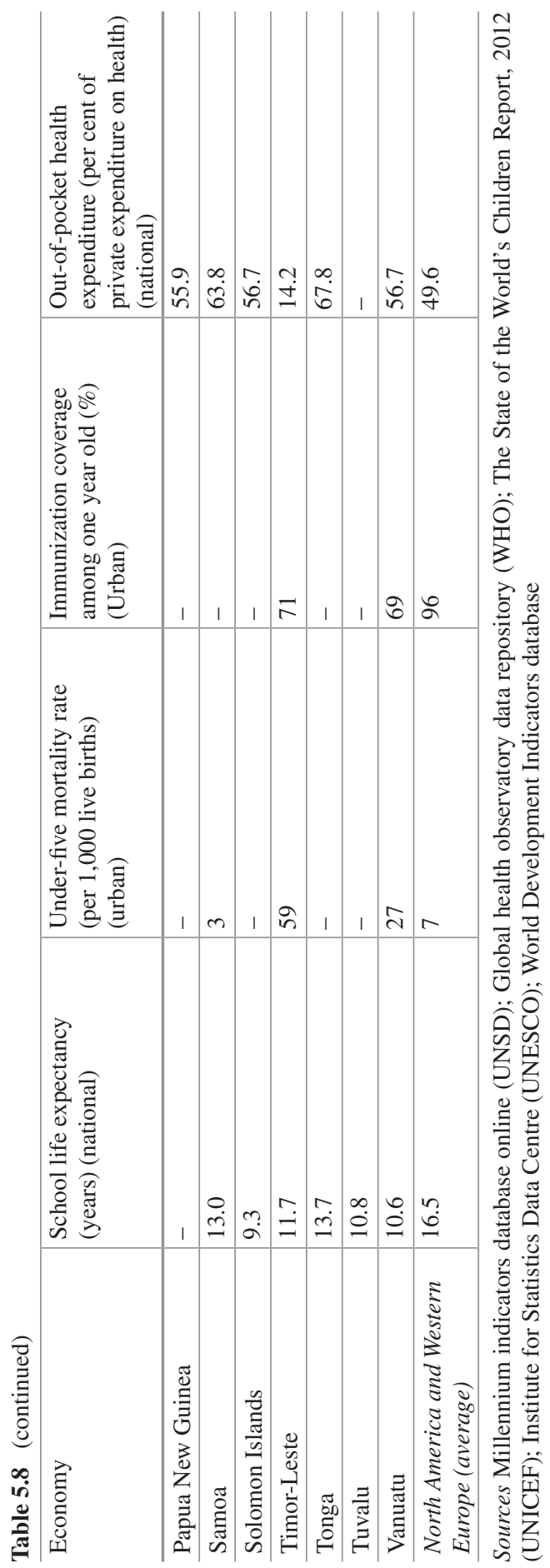


Table 5.9 Government expenditures on education, health and social security and welfare (percentage of total expenditure), Asian economies: 2011

\begin{tabular}{|c|c|c|c|}
\hline Economy & $\begin{array}{l}\text { Government } \\
\text { expenditure on } \\
\text { education }\end{array}$ & $\begin{array}{l}\text { Government } \\
\text { expenditure on health }\end{array}$ & $\begin{array}{l}\text { Government } \\
\text { expenditure on social } \\
\text { security and welfare }\end{array}$ \\
\hline Developing Asia & 14.9 & 5.0 & 9.4 \\
\hline $\begin{array}{l}\text { Central and West } \\
\text { Asia }\end{array}$ & - & - & - \\
\hline Afghanistan & - & - & - \\
\hline Armenia & 11.4 & 6.7 & 35.7 \\
\hline Azerbaijan & 8.2 & 3.2 & 9.7 \\
\hline Georgia & 8.8 & 5.4 & 20.8 \\
\hline Kazakhstan & - & - & - \\
\hline Kyrgyz Republic & 21.3 & 10.4 & 15.6 \\
\hline Pakistan & - & - & - \\
\hline Tajikistan & 16.7 & 6.5 & 12.8 \\
\hline Turkmenistan & - & - & - \\
\hline Uzbekistan & - & - & - \\
\hline East Asia & - & - & - \\
\hline The PRC & 14.0 & 5.3 & 10.2 \\
\hline Hong Kong, China & 17.6 & 11.6 & 11.2 \\
\hline Republic of Korea & 15.1 & 1.0 & 22.2 \\
\hline Mongolia & 13.3 & 6.9 & 36.2 \\
\hline Taipei,China & 13.1 & 1.4 & 23.4 \\
\hline South Asia & - & - & - \\
\hline Bangladesh & 11.4 & 5.6 & 2.1 \\
\hline Bhutan & 17.9 & 6.9 & 4.9 \\
\hline India & 16.5 & 4.0 & 5.6 \\
\hline Maldives & 14.6 & 3.1 & 7.7 \\
\hline Nepal & 17.9 & 7.2 & 3.2 \\
\hline Sri Lanka & 8.6 & 6.3 & 8.7 \\
\hline Southeast Asia & - & - & - \\
\hline Brunei Darussalam & 18.3 & 8.3 & 4.8 \\
\hline Cambodia & 13.7 & 12.2 & 5.2 \\
\hline Indonesia & - & - & - \\
\hline Lao PDR & - & - & - \\
\hline Malaysia & 21.6 & 7.5 & 3.6 \\
\hline Myanmar & - & - & - \\
\hline The Philippines & 16.5 & 2.3 & 5.7 \\
\hline Singapore & 21.0 & 8.1 & 7.7 \\
\hline Thailand & 19.4 & 9.9 & 6.8 \\
\hline Viet Nam & - & - & - \\
\hline
\end{tabular}


Table 5.9 (continued)

\begin{tabular}{l|l|l|l}
\hline Economy & $\begin{array}{l}\text { Government } \\
\text { expenditure on } \\
\text { education }\end{array}$ & $\begin{array}{l}\text { Government } \\
\text { expenditure on health }\end{array}$ & $\begin{array}{l}\text { Government } \\
\text { expenditure on social } \\
\text { security and welfare }\end{array}$ \\
\hline The Pacific & - & - & - \\
\hline Cook Islands & 13.4 & 11.2 & - \\
\hline Fiji & 27.7 & 15.1 & 0.5 \\
\hline Kiribati & 18.6 & 16.3 & 3.1 \\
\hline Marshall Islands & - & - & - \\
\hline Micronesia & - & - & - \\
\hline Nauru & - & - & - \\
\hline Palau & - & - & - \\
\hline Papua New Guinea & 10.0 & 5.7 & 1.5 \\
\hline Samoa & 19.8 & 17.9 & 4.3 \\
\hline Solomon Islands & - & - & - \\
\hline Timor-Leste & 6.2 & 3.6 & 9.1 \\
\hline Tonga & - & - & - \\
\hline Tuvalu & - & - & - \\
\hline Vanuatu & 26.1 & 10.8 & 0.2 \\
\hline Asia (average) & 15.3 & 8.9 & 12.9 \\
\hline $\begin{array}{l}\text { North America and } \\
\text { Western Europe } \\
\text { (average) }\end{array}$ & 23.3 & 9.5 & 22.2 \\
\hline Source Frang & & & \\
\hline
\end{tabular}

Source Framework of inclusive growth indicators, 2012 (ADB)

Developing Asia also has much lower levels of public spending on education and health than the developed countries. ${ }^{11}$ Developing Asia, on an average, spent just $14.9 \%$ of the total government expenditure on education and $5 \%$ on health, as against $23.3 \%$ on education and $9.5 \%$ on health in North America and Western Europe (Table 5.9).

Government expenditure on education was less than $10 \%$ of the total government expenditure in Timor-Leste, Azerbaijan, Sri Lanka and Georgia. Government expenditure on health was less than $5 \%$ of the total government expenditure in Azerbaijan, Republic of Korea, Taipei,China, the PRC, India, Maldives, the Philippines and Timor-Leste.

Government expenditure on social security and welfare was generally low in most of developing Asia. ${ }^{12}$ The average for developing Asia is just $9.4 \%$, as

\footnotetext{
11 Government expenditure on education consists of expenditure by government to provide education services at all levels. Government expenditure on health consists of expenditure by government to provide medical products, appliances and equipment; outpatient services; hospital services; public health services; etc.

12 This is the government expenditure that provides benefits in cash or kind to persons who are sick, fully or partially disabled, of old age, survivors, families and children, unemployed or socially excluded, among others.
} 
Table 5.10 Working poverty, world and Asian regions: 2002 and 2012

\begin{tabular}{|c|c|c|c|c|c|c|c|c|c|c|}
\hline Region & World & & East A & & $\begin{array}{l}\text { South } \\
\text { Asia a } \\
\text { Pacifi }\end{array}$ & $\begin{array}{l}\text { East } \\
\text { d the }\end{array}$ & South & Asia & Asia & \\
\hline Year & 2002 & 2012 & 2002 & 2012 & 2002 & 2012 & 2002 & 2012 & 2002 & 2012 \\
\hline $\begin{array}{l}\text { Number of } \\
\text { working poor } \\
\text { at the US } \$ 1.25 \\
\text { a day level } \\
\text { (million) }\end{array}$ & 663.5 & 383.8 & 204.4 & 46.3 & 66.5 & 35.4 & 232.3 & 155.9 & 503.2 & 237.7 \\
\hline $\begin{array}{l}\text { Number of } \\
\text { working poor } \\
\text { at the US\$2 } \\
\text { a day level } \\
\text { (million) }\end{array}$ & 1173.1 & 853.7 & 372.9 & 113.2 & 136.3 & 98.3 & 417.0 & 391.2 & 926.2 & 602.7 \\
\hline $\begin{array}{l}\text { Share of } \\
\text { working poor } \\
\text { at US\$1.25 } \\
\text { a day in total } \\
\text { employment } \\
(\%)\end{array}$ & 24.6 & 12.3 & 26.9 & 5.6 & 26.7 & 11.7 & 42.9 & 24.4 & 32.2 & 13.9 \\
\hline $\begin{array}{l}\text { Share of work- } \\
\text { ing poor at } \\
\text { US\$2 a day in } \\
\text { total employ- } \\
\text { ment }(\%)\end{array}$ & 43.5 & 27.3 & 49.1 & 13.6 & 54.6 & 32.5 & 77.1 & 61.3 & 60.3 & 35.8 \\
\hline
\end{tabular}

Source Key Indicators of the Labour Market, ILO database

against an average of $22.2 \%$ in North America and Western Europe. Of the 28 developing Asian economies, 10 had percentages below $5 \%$, among them the major countries being India, Bangladesh, Nepal, Malaysia and Azerbaijan.

\subsection{Lack of Access to Decent Livelihood (Working Poverty)}

Working poverty is typically high in Asia, and the majority of the working poor eke a living in the informal sector in vulnerable conditions. The decent work deficits of those employed in the informal economy include poor-quality, unproductive and un-remunerative jobs that are not recognized or protected by law, absence of rights at work, inadequate social protection and lack of representation and voice (ILO 2013a, b). 


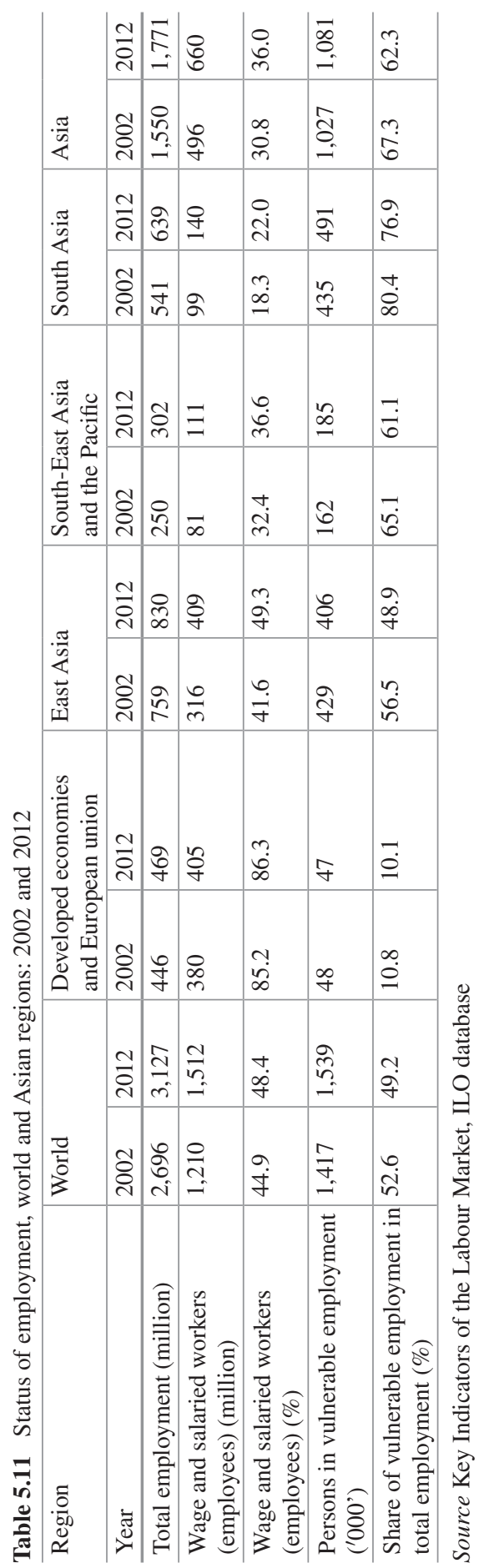


In $2002,84.4 \%$ of the working poor ${ }^{13}$ (at the US\$2 a day level) of the world were concentrated in Asia (Table 5.10). Though this share has come down, that of Asia in 2012 was still unacceptably high at $78.9 \%$. Also, the share of the working poor in total employment in Asia at both levels (US\$1.25 a day and US\$2 a day) is much higher than the world average, especially those in moderate poverty. The numbers are completely abysmal in South Asia, where $24.4 \%$ of the working population is under extreme poverty and, what is more alarming, $61.3 \%$ of the working population is under moderate poverty.

The proportion of the wage and salaried workers is the lowest in Asia, while the incidence of vulnerable employment is the highest (Table 5.11). In developing Asia, nearly 1.1 billion workers $(62.3 \%)$ are classified as own-account or contributing family workers with limited job stability, earnings and protection (ILO 2013a, b). These workers are often informally employed, with few opportunities for regular, salaried employment. In 11 of the developing economies in Asia, less than one in two workers is engaged in paid wage employment. In Bangladesh, Pakistan, India, Lao PDR and Nepal, salaried work accounts for less than one-fifth of all jobs.

\subsection{Conclusion}

There is a stark dichotomy between the income and non-income indicators of urban poverty and a gross underestimation of urban poverty in developing Asia. The case of the PRC is especially interesting in this context. There is a need to broaden the definition of urban poverty beyond just the austere threshold of meeting the survival needs of food (nutrition) to one that meets a minimal set of basic needs and capabilities, which takes into account the huge deprivations related to shelter, access to basic infrastructure, access to health, education and social welfare, vulnerability in working conditions and working poverty. Adopting broader and higher poverty thresholds that would faithfully report urban poverty, however, is only the initial step in the formulation of a forward-looking urban poverty reduction strategy for developing Asia. But it is an important first step as it can be critical for focusing policy attention on the right target group. The new thresholds should form the basis of not only the measurement and monitoring of poverty in the country, but also, more importantly, the development of a consistent operational approach to targeting a range of poverty alleviation, housing, social protection and livelihood and decent job creation programs to the urban poor, combined with a focus on breaching the inequities between the poor and the non-poor, especially in the fields of health, education and access to basic infrastructure. It is critically important to do so because how developing Asia deals with the challenge of

\footnotetext{
${ }^{13}$ Working poor, according to the ILO definition, comprise the number of employed persons living in households in which per capita income/expenditure is below the poverty line, where employment status is determined at the individual level and poverty at the household level.
} 
urban poverty would largely determine the pace of global urban poverty reduction in the coming decades.

It is now well acknowledged that poverty is inherently multidimensional in nature. Poverty analysis took a new broader dimension when Amartya Sen introduced and developed the capability approach that viewed poverty as a multidimensional concept and not just a result of deprivation of a single resource. The concept of capability has been extremely influential at both the academic and institutional levels. It has shaped the aggregate alternatives devised and implemented by the United Nations Development Programme's (UNDP) Human Development Initiative, which, since the 1990s, have measured the progress of individual well-being, and, with the introduction of the Human Development Index (HDI), could serve as a frame of reference for both social and economic development, by combining indicators of life expectancy, educational attainment and income into a composite index. Since the beginning of the new millennium, a host of indicators called the MDGs are being tracked in the context of the United Nations' Millennium Development Initiative. Eight MDGs with 18 measurable time-bound targets and 48 indicators were drafted to translate the commitment into reality by the end of 2015. The goals covered major aspects of social development, including eradicating extreme hunger and poverty; achieving universal primary education; promoting gender equality; reducing child mortality; improving maternal health; combating HIV/AIDS, malaria and other diseases; ensuring environmental sustainability; and developing a global partnership for development. The MDG discourse, thus, went well beyond the monetary approach and encompassed a number of fundamental capabilities. Measuring socio-economic progress, thus, gained pace, and demand for indicators from microsurveys also increased across the world. The Oxford Poverty and Human Development Initiative (OPHI) has developed an international poverty measure called the multidimensional poverty index (MPI), which was included for the first time in the UNDP flagship Human Development Report in 2010. The index reflects the multiple deprivations that a poor person faces with respect to education, health and living standards. It is a composite measure from microsurveys with a set of indicators that has overlapping areas with the MDGs.

Urban poverty, as discussed, is inherently much more multidimensional in nature than rural poverty or national poverty. But the measurement of the extent or the incidence of the multidimensional urban poverty is inhibited by the huge data gaps that exist across most nations in Asia (this would be true for the world as a whole) related to almost all the income and the non-income dimensions of urban poverty that have been discussed. Neither comparable estimates for income urban poverty for Asian nations (except three countries) nor most education and health indicators by their rural and urban splits are available. Working poverty data are available only at the regional level. Only the service delivery parameters of water and sanitation are available across urban parts for a reasonable number of countries. Thus, though extremely pertinent, it is impossible to come up with a multidimensional urban poverty index across the Asian nations (or for that matter, for most of the other countries in the world). The UN-HABITAT's functional 
definition of slums and the data corresponding to that, which forms a part of the UN Global Urban Indicators Database, are the only attempt at the global level that attempts to come up with a multidimensional urban poverty measure that is comparable across countries. As discussed, this definition not only measures the slum population, but also encompasses the deprivations of urban populations of countries related to the four dimensions of housing/shelter, congestion, water and sanitation. In the absence of country-level comparable data sets on the income and non-income urban poverty parameters, it is not possible to go beyond this definition and database. But even the basic urban deprivation index developed by UN-HABITAT is enough to put forward a strong case to point out the gross underestimation of urban poverty, as well as the dichotomy between the income and non-income dimensions of urban poverty for the Asian nations. It is very important to broaden the concept of urban poverty and start measuring the income as well as the various non-income dimensions of urban poverty across nations at regular fixed intervals through national microsurveys. The results can then be analysed by researchers or international organizations to come up with comparable estimates for each of the dimensions, as well as for the construction of a composite multidimensional urban poverty measure across nations.

Open Access This chapter is distributed under the terms of the Creative Commons Attribution Noncommercial License, which permits any noncommercial use, distribution, and reproduction in any medium, provided the original author(s) and source are credited.

\section{References*}

Asian Development Bank (2012a) Key indicators for Asia and the Pacific. Metro Manila, Philippines

Asian Development Bank (2012b) Key indicators for Asia and the Pacific: framework of inclusive growth indicators: special supplement. Metro Manila, Philippines

Asian Development Bank (2012c) Infrastructure for supporting inclusive growth and poverty reduction in Asia. Metro Manila, Philippines

Bartlett S (2011) Children in urban poverty: can they get more than small change? UNICEF Child Policy Insights

Cheng TJ (2003) China's Hukou system in the 1990s and beyond. In: Presentation at the international conference, City University of New York, College of Staten Island, USA

Foggin P (2008) Urban poverty and urban slums in People's Republic of China, Lausanne, World Pulse blog

Haddad L (2013) Poverty is urbanizing and needs different thinking on development, Poverty Matters blog

Hasan R, Maria Rhoda M, Salcedo Cain J (2009) Poverty impact of the economic slowdown in developing Asia: some scenarios, ADB economics working paper series no. 153, Mandaluyong City, Metro Manila, Philippines

International Labour Organization (2013a) Global wage report 2012/13: wages and equitable growth. Geneva

\footnotetext{
* ADB recognizes "China" as the People's Republic of China.
} 
International Labour Organization (2013b) Global employment trends 2013: recovering from a second jobs dip. Geneva

Miller Tom (2013) China's urban billion: the story behind the biggest migration in human history (Asian arguments). Zed Books, London

Mitlin D (2004) Understanding urban poverty; what the poverty reduction strategy papers tell us, human settlements working paper series, poverty reduction in urban areas no. 13. IIED, London

Ravallion M, Shaohua C, Prem S (2007) New evidence on the urbanization of global poverty. World bank policy research working paper 4199, World Bank, Washington D.C

Satterthwaite D (2002) Reducing urban poverty: some lessons from experience. International Institute for Environment and Development (IIED working paper)

Satterthwaite D (2004) The under-estimation of urban poverty in low-and middle-income nations. International Institute for Environment and Development working paper no.14. London

Solinger DJ (2004) The creation of a new underclass in People's Republic of China and its implications, paper prepared for POSRI international forum on China's development: key challenges for China's sustained growth, Seoul, Korea, 10-11 Nov 2004

UNICEF and World Health Organization (2012) Progress on drinking water and sanitation: 2012 update, WHO/UNICEF joint monitoring programme for water supply and sanitation

United Nations Department of Economic and Social Affairs (UNDESA) (2009) Regional trends, issues and practices in urban poverty reduction: social protection in Asian cities

United Nations Department of Economic and Social Affairs (UNDESA) (2012) World urbanization prospects: the 2011 revision, New York

United Nations Economic and Social Commission for Asia and the Pacific (UNESCAP) (2011) Statistical yearbook for Asia and the Pacific 2011, Thailand

United Nations Human Rights Council (UNHRC) (2012) Study on the promotion of human rights of the urban poor: strategies and best practices

United Nations Human Settlements Programme (UN-HABITAT) (2003) The challenge of slums: global report on human settlements 2003. Earthscan, Nairobi, Kenya

United Nations Human Settlements Programme (UN-HABITAT) (2010) The state of Asian cities 2010/11. Regional Office for Asia and the Pacific, Fukuoka, Japan

United Nations Human Settlements Programme (UN-HABITAT) (2012) state of the world's cities 2012/2013: prosperity of cities. Earthscan, Nairobi, Kenya

World Bank and International Monetary Fund (2013) Global monitoring report 2013: rural-urban dynamics and the millennium development goals. Advance Edition, Washington DC

World Health Organization (2013) The world health report 2013: research for universal health coverage, Geneva

Wu Fulong, Webster Chris, He Shenjing, Liu Yuting (2010) Urban poverty in People's Republic of China. Edward Elgar, Cheltenham, UK 